\title{
Phase I single center trial of Ketogenic Diet for Adults with Traumatic Brain Injury
}

\section{Authors:}

1. Niraj Arora, MD Assistant Professor in Neurology, University of Missouri,Columbia, Missouri, United States.

2. N. Scott Litofsky, MD Professor and Chief of Neurological Surgery, University of Missouri, Columbia, Missouri, United States

3. Golzy Mojgan, PhD. Assistant Research Professor, University of Missouri,Columbia, Missouri, United States

4. Rachna Aneja, PhD, Research Scientist, Molecular Microbiology and Immunology, University of Missouri, Columbia, Missouri, United States

5. Danielle Staudenmyer, RD, Clinical Dietician, University of Missouri, Columbia, Missouri, United States

6. Kathyrn Qualls, Clinical Pharmacist Specialist, University of Missouri, Columbia, Missouri, United States

7. Sachin Patil, MD, Critical Care Fellow, Department of Internal Medicine, University of Missouri, Columbia, Missouri, United States

\section{Corresponding author:}

Niraj Arora

1 Hospital Dr, CE545

Columbia, MO 65212

Email address: $\underline{\text { arorana@ @ealth.missouri.edu }}$

Phone number: 573-884-7975

Word count: 3305

Number of Tables: 2

Number of Supplementary Tables: 3

Number of Figures: 5

Keywords: Traumatic Brain injury, Ketogenic diet, ketosis, beta-hydroxybutyrate, glucose. 
medRxiv preprint doi: https://doi.org/10.1101/2021.07.19.21260800; this version posted July 22, 2021. The copyright holder for this preprint (which was not certified by peer review) is the author/funder, who has granted medRxiv a license to display the preprint in perpetuity. It is made available under a CC-BY-NC-ND 4.0 International license .

The authors hereby confirm that the manuscript complies with all instructions to authors, authorship requirements have been met and the final manuscript was approved by all authors, this manuscript has not been published elsewhere and is not under consideration by another journal, manuscript is adherent to ethical guidelines and ethical approvals (IRB) and use of informed consent was obtained. as appropriate.

10 None of the authors have any conflict of interest. 
medRxiv preprint doi: https://doi.org/10.1101/2021.07.19.21260800; this version posted July 22, 2021. The copyright holder for this preprint (which was not certified by peer review) is the author/funder, who has granted medRxiv a license to display the preprint in perpetuity.

It is made available under a CC-BY-NC-ND 4.0 International license .

\title{
Phase I single center trial of Ketogenic Diet for Adults with Traumatic Brain Injury
}

\begin{abstract}
:
Background: Traumatic Brain injury (TBI) is a major cause of mortality and morbidity in the United States. Ketogenic diet (KD) has been shown to have neuroprotective effects in acute brain injury, but limited data about its use in adult TBI patients is available. The objective of this study is to investigate the feasibility and safety of ketogenic diet (KD) for adult TBI patients in the Neuroscience Intensive Care Unit (NSICU).
\end{abstract}

Methods: TBI patients admitted to NSICU between June 2019 to March 2021 were enrolled in this single-center, open label, single-arm prospective intervention study. The primary feasibility outcome was achievement of ketosis (detection and maintenance of serum beta-hydroxybutyrate (BOB) levels above normal); secondary outcomes included laboratory and clinical adverse effects related to $\mathrm{KD}$.

Results: 10 adults with TBI with Abbreviated Injury Score (AIS)-Head of at least 3 and ventriculostomy tube inserted met inclusion/exclusion criteria and were considered for KD. Mean age was47 years, and all patients were male. Eight out of 10 patients achieved ketosis within mean 2.2 days. KD was initiated within 8-33 hours (average 23 hours) of hospital admission. No clinical adverse effects were noted, 2 patients developed hypertriglyceridemia and 1 patient developed hypoglycemia. Serum glucose showed a decreasing trend in most patients.

Conclusions: This pilot study shows that KD is feasible and safe in the management of TBI patients. A randomized controlled trial (RCT) is justified to further understand the optimal serum BOB levels, dose and duration of KD in TBI and its effect on the outcome. 
medRxiv preprint doi: https://doi.org/10.1101/2021.07.19.21260800; this version posted July 22, 2021. The copyright holder for this preprint (which was not certified by peer review) is the author/funder, who has granted medRxiv a license to display the preprint in perpetuity.

It is made available under a CC-BY-NC-ND 4.0 International license .

\section{Introduction}

Traumatic brain injury (TBI) is a major cause of death and disability in young adults contributing to nearly one-third of injury related deaths in the United States. An estimated 13.5 million individuals live with disability after TBI in the United States, creating and significant economic burden on the health-care system and the family[1]. TBI is complicated by development of secondary cerebral injury involving a host of cellular and molecular cascades that promote cell death leading to worsening of cerebral edema and ischemia[2], [3]. Disturbances in ion homeostasis, glutamate excitotoxicity, neuronal depolarization, generation of nitric oxide and oxygen free radicals, lipid peroxidation, and mitochondrial dysfunction results in inflammation, apoptosis, and necrotic cell death [2]. In TBI with initial Glasgow Coma Scale (GCS) 3-5, survival is only $20 \%$ and out of that, only $50 \%$ patients have good functional outcome. [4] Therefore, development of new strategies and approaches to understand and reverse the neuronal damage is essential. One proposed treatment is the use of a high fat-containing diet known as the KetogenicDiet (KD).

$\mathrm{KD}$, developed in 1920s, mimics the biochemical environment present during a period of limited food availability [5]. The diet consists of high fat, adequate protein, and very minimal carbohydrates which enhance cellular metabolic and mitochondrial functions [6]. Medium chain fatty-acids derived from the KD have been shown to have a therapeutic role in management of different neurological disorders[5], [7]-[11]. In animal studies with TBI, KD decreases the oxidative stress response and improves mitochondrial function[12]. A corresponding reduction in lactate levels occurs and improvement in energy metabolism occurs in animals treated with KD compared to standard carbohydrate diet [12]. In humans with TBI, administration of glucose leads 
medRxiv preprint doi: https://doi.org/10.1101/2021.07.19.21260800; this version posted July 22, 2021. The copyright holder for this preprint (which was not certified by peer review) is the author/funder, who has granted medRxiv a license to display the preprint in perpetuity.

It is made available under a CC-BY-NC-ND 4.0 International license .

1 to inhibition of ketogenesis and increases production of lactate levels in the brain [12]. After TBI,

2 metabolic changes including hyperglycemia, high cerebral glutamate levels, and high

3 lactate/pyruvate ratio occur [2], [3]. These changes lead to poor clinical outcomes after TBI[13].

$4 \quad \mathrm{KD}$ has been tried as a therapy in number of chronic neurological disease like Alzheimer's Disease

5 (AD)[7], childhood epilepsy[14],[15], and Parkinson's Disease [16]. While KD has been considered

6 as a safe, feasible and effective therapeutic option in status epilepticus patients due to various causes

7 including TBI, the safety and feasibility of KD in adult humans with TBI has not been studied [10], $8 \quad[17]$.

The current Phase I study describes the single center ICU experience regarding the safety and

12 feasibility of KD for TBI patients. We hypothesize that KD may be safe and feasible in patients 13 with TBI in ICU.

\section{Methods:}

Standard Protocols and Consents:

The study was approved by the University of Missouri Institutional Review Board (IRB), Protocol number 2014675, ClinicalTrials.gov Identifier: NCT03982602. Appropriate consent for the study was obtained from the patient's next of kin or designated power of attorney at the time of admission. Due diligence was taken to adhere to the ethical standards as defined by the IRB.

\section{Study design:}

Adult patients greater than 18 years old admitted to Neuroscience Intensive Care Unit (NSICU) at University of Missouri Hospital and Clinics, Columbia, USA (United States of America) between Ire 2019 to March 2021 with TBI with Abbreviated Injury Score (AIS)-Head of at least 3 and ventriculostomy catheter or intracranial pressure monitor inserted were eligible to participate in 
medRxiv preprint doi: https://doi.org/10.1101/2021.07.19.21260800; this version posted July 22, 2021. The copyright holder for this preprint (which was not certified by peer review) is the author/funder, who has granted medRxiv a license to display the preprint in perpetuity. It is made available under a CC-BY-NC-ND 4.0 International license .

1 this single-center, open label, single-arm prospective intervention Phase I study to evaluate the 2 safety and feasibility of ketogenic diet in TBI patients. Exclusion criteria[17] included patients

3 with diabetic ketoacidosis, hypoglycemia (glucose $<70 \mathrm{mg} / \mathrm{dl}$ ), acute liver failure (liver enzymes x5upper limit of normal and/or total bilirubin > 15mg/dl), hypertriglyceridemia (TG > 200mg/dl), history of pancreatitis, inability to tolerate enteral feeds including ileus, diagnosed case of fatty acid oxidation disorder or pyruvate carboxylase deficiency, pregnant females, death or withdrawal of care within 48 hours of admission, inability to obtain consent from the patient's decision maker.

\section{Study Outcomes}

Primary feasibility outcome of the study was achievement of ketosis: detection and maintenance of serum beta-hydroxybutyrate (BOB) levels above normal [>0.27mmol/1][18]. Serum BOB levels were measured before initiating KD (baseline) and then daily.

Main safety outcome of the study was development of laboratory abnormalities such as hypoglycemia :glucose $<70 \mathrm{mg} / \mathrm{dl}$, mild, moderate or severe hypertriglyceridemia (Triglyceride $\{\mathrm{TG}\}$ levels $150-199 \mathrm{mg} / \mathrm{dL}$ (1.7-2.3 mmol/L), 200-999 mg/dL (2.3 to $11.3 \mathrm{mmol} / \mathrm{L})$, or $1000-1999 \mathrm{mg} / \mathrm{dL}$ (11.3-22.6 mmol/L respectively) [19], metabolic acidosis $(\mathrm{pH}<7.2)$, significant electrolyte disturbances (sodium less than $130 \mathrm{mg} / \mathrm{dl}$ or more than $150 \mathrm{mg} / \mathrm{dl}$, potassium less than $3 \mathrm{mg} / \mathrm{dl}$ or more than $5 \mathrm{mg} / \mathrm{dl}$ ), acute liver failure (liver enzyme elevation x 5 times the upper limit of normal), acute kidney injury (elevation in serum creatinine above normal for age) and clinical adverse effects like nausea, vomiting, abdominal distension, diarrhea.

Glucose levels were measured daily while fasting lipid levels were measured weekly. Lowest level of blood glucose during the day was reported while the patient was on KD. The requirement of the insulin per day for each patient was calculated while on KD. 
medRxiv preprint doi: https://doi.org/10.1101/2021.07.19.21260800; this version posted July 22, 2021. The copyright holder for this preprint (which was not certified by peer review) is the author/funder, who has granted medRxiv a license to display the preprint in perpetuity.

It is made available under a CC-BY-NC-ND 4.0 International license .

\section{Patient Management}

All patients admitted to the NSICU with severe TBI received standard of care management per the Brain Trauma Foundation guidelines[20]. Surgical evacuation with craniotomy or craniectomy, external ventricular drain (EVD) placement for cerebrospinal fluid (CSF) diversion and intracranial pressure (ICP) monitoring, hypertonic solutions as indicated, sedation, analgesia and paralytics as needed with appropriate medications, antibiotics for infection, seizure prophylaxis, and mechanical ventilation were provided. Marshall Computerized Tomography (CT) score [21] was determined on all included patients. Utmost care was taken to provide the medications that contain minimal or no carbohydrates [22] and the doses were verified by the pharmacist.

\section{Nutritional management}

All patients enrolled in the study protocol were given glucose-free intravenous fluids during resuscitation in emergency room, operating room, or NSICU. Ketogenic diet was started as soon as the patient was ready for alimentation (while they were in NSICU). The rate of feeds was calculated by a trained dietician. Ketogenic diet was continued via nasogastric or orogastric tube during the entire NSICU LOS with inability to swallow. In all other conditions, KD was replaced with the standard carbohydrate diet. The duration of KD therapy was determined and side effects and complications of KD were monitored. If the patient was not able to tolerate the KD due to side effects and/or developed abdominal distension or ileus, then KD was discontinued for 24 hours before resumption. Confounding factors in the form of excessive sedation and medications were managed per the treating intensivist. 
medRxiv preprint doi: https://doi.org/10.1101/2021.07.19.21260800; this version posted July 22, 2021. The copyright holder for this preprint (which was not certified by peer review) is the author/funder, who has granted medRxiv a license to display the preprint in perpetuity.

It is made available under a CC-BY-NC-ND 4.0 International license .

1 Resting Metabolic Rate (RMR) was calculated using the Penn State Formular, as follows: RMR =

2 (Mifflin-St. Jeor x 0.96) + (VE x 32) + (Tmax x 167) - 6212, where VE is minute ventilation

3 ( $\mathrm{L} / \mathrm{min})$ and Tmax is maximum body temperature in the previous 24 hours in $^{\circ}$ Celsius.

4 with the Mifflin-St Jeor formula following:

Men: $(10 \times$ weight in $\mathrm{kg})+(6.25 \times$ height in $\mathrm{cm})-(5 \times$ age in years $)+5$

Women: $(10 \times$ weight in $\mathrm{kg})+(6.25 \times$ height in $\mathrm{cm})-(5 \times$ age in years $)-161$

Protein requirement (1.5-2 gm/kg of body weight) were met with Prosource $®$, which contains only

11 protein and no carbohydrate. If the patient was receiving propofol for sedation, the calories of its

12 lipid content were factored into while calculating the total daily calorie input. Attempt wasmade to

13 wean propofol off as early as possible to avoid the potential confounding toxic side effects of

14 propofol. Clevedipine infusions, were changed to nicardipine infusions for blood pressure control,

15 since they also contain lipids.

\section{Descriptive Study Statistics}

17

A sample size of 10 patients was chosen for this phase I pilot study [23]. Proportions were calculated for categorical variables, and means, medians and interquartile ranges(IQRs) were calculated for continuous variables as appropriate. Graphical techniques were used for visualization of trends in glucose, and serum BOB levels with time. A simple regressionanalysis was used to estimate the daily change in these values. Due to small sample size, we did not include the random variability among the individuals. We looked at the relationship between BOB and time using a simple linear regression.

\section{Results}

\section{Patient Characteristics}

Ten patients identified who met the study inclusion/exclusion criteria (Figure1) were eligible and 
medRxiv preprint doi: https://doi.org/10.1101/2021.07.19.21260800; this version posted July 22, 2021. The copyright holder for this preprint (which was not certified by peer review) is the author/funder, who has granted medRxiv a license to display the preprint in perpetuity.

It is made available under a CC-BY-NC-ND 4.0 International license .

1 started on KD therapy. The mean age of included patients was 47.7 years with \pm 15.02 (range $28-76$

2 years); all patients were Caucasian males. Only 1 patient had type 2 diabetes mellituson admission, 4

3 patients had history of alcohol abuse, 4 patients had history of smoking, 2 patients had

4 methamphetamine abuse, 1 patient had history of hypertension, arrythmias and chronic kidney

5 disease.

6

7 Etiology of TBI was related to fall from height (5), fall due to drug intoxication (2), motor vehicle

8 accident (1), mechanical fall (1), and direct trauma to head due to firework mortar (1). Marshall

9 Computerized Tomography (CT) Score was 5 in 7 patients, 4 in 1 patient and 2 in 2 patients.

10 Abbreviated Injury Score (AIS)-Head was 5 in 8 patients, 4 and 3 in 1 patient each. Craniectomy was

11 performed in 2 patients, craniotomy in 5 patients, and all patients had EVD. Eight patients were

12 on propofol infusion for sedation management initially. The maximum dose of the propofol infusion

13 was $55 \mathrm{mcg} / \mathrm{kg} / \mathrm{hour}$, which was gradually weaned off once the decision was made to start the patient

14 on KD. Admission GCS was $<8$ in all patients except in one. However, patient's GCS declined to

$155 \mathrm{t}$ (E1V1tM3) within 24h of ICU admission and prompted urgent surgical intervention.

16

17

18

19

20

21

22

23

24

25

26

27

\section{Ketogenic diet ratio}

All the patients were started on standard formulation of ketogenic diet (Ketovie 4:1) (Table 1). After the correction of the protein requirement, the net ratio averaged 1.33: 1 (range: 1.1-1.76:1).

\section{Outcomes after KD initiation (Primary outcome)}

Eight out of ten patients achieved ketosis and maintained ketosis after initiation of KD (Table 2).

The presence of ketones in the serum was seen as early as day 1 (average 2.2 days \pm 2.14 days, range 1 - 8 days). The duration of KD ranged from $4-14$ days, with most patients receivingthe therapy for at least 1 week. Four patients had elevated BOB levels before starting of KD which may be related to fasting [24]. KD was initiated within 8-33 hours (average 23 hours) of hospital 
medRxiv preprint doi: https://doi.org/10.1101/2021.07.19.21260800; this version posted July 22, 2021. The copyright holder for this preprint (which was not certified by peer review) is the author/funder, who has granted medRxiv a license to display the preprint in perpetuity.

1 admission.

2 Two patients did not achieve ketosis during the ICU stay (patient 2, 8). On evaluation, the net KD ratio

3 was 1.1:1 for patient 2. The family opted for withdrawal of care due to refractory ICP elevation.

4 Patient 8 did not achieve ketosis until day 10 when propofol was added to the KD. The net KD

5 ratio was 1.35:1. However, the triglyceride levels increased to $325 \mathrm{mg} / \mathrm{dl}$. The patient was

6 continued on KD but he remained in comatose condition throughout the NSICU stay and family

7 decided to discontinue the care. For patient 9, therapy wasstopped after 4 days as he recovered

8 neurologically and was extubated and ventriculostomy was removed. However, patient had other

9 medical issues after the extubation which prompted him to stay in the hospital for 15 additional

10 days. The remaining patients achieved ketosis as measured with serum BOB levels above

$110.27 \mathrm{mmol} / 1$. Patient 7 continued to have poor neurological exam and familydecided to withdraw the

12 care. The patient's serum BOB levels remained low despite being on KD. (Net KD ratio 1.36:1)

13

Serum BOB levels fluctuated for each patient (Figure 2). However, a linear relationship between serum BOB and time was observed(Figure 3).

\section{Secondary outcomes (Table 3)}

No patients had metabolic complications, such as metabolic acidosis, significant electrolyte disturbances, acute liver failure, acute kidney injury or troponinemia. None of the patients developed acute liver failure or propofol infusion syndrome related to the use of propofol with KD.

Two patients (patient 1 and 8) developed hyper-triglyceridemia. Serum blood glucose levels decreased with time in all patients, even if thepatient had not achieved a ketotic state. One patient (patient 10) developed hypoglycemia which required dextrose infusion once. The case was adjudicated and it was determined that KD was the cause of hypoglycemia. However, he did not 
medRxiv preprint doi: https://doi.org/10.1101/2021.07.19.21260800; this version posted July 22, 2021. The copyright holder for this preprint (which was not certified by peer review) is the author/funder, who has granted medRxiv a license to display the preprint in perpetuity.

It is made available under a CC-BY-NC-ND 4.0 International license.

1 have any recurrent episodes of hypoglycemia and tolerated the KD.

\section{Effect on glucose and insulin requirement}

Glucose levels showed a decreasing trend (Figure 4) and the fitted regression model showed an estimated 3.9mg/dl daily decrease (Figure 5). The individual random variation in glucose level was not considered in the fitted model due to the small number of patients.. After initiation of KD, only 3 patients required insulin. Patient 2 and 9 required 3 units of insulin on day 1 and patient 7 who had poorly controlled diabetes on admission continued to have increased insulin requirement throughout the ICU stay. (Supplementary table 2)

\section{Discussion}

We report a phase I pilot study of TBI patients treated with KD. Most patients achieved ketosis and tolerated the KD without significant clinical adverse effects. Our results about safety of KD are similar to those of patients with status epilepticus. [10], [17], [25]. Adverse effects like hypoglycemia and hypertriglyceridemia were noted in some of the patients. Attempts were not made to achieve higher ketosis levels in our study. Fasting can influence the BOB levels and levels as high as $1 \mathrm{mmol} / \mathrm{l}$ can be achieved during fasting and starvation[24] however this may not be a feasible and safe option in critical brain injuries. Maintenance of ketosis is essential to understand the beneficial effects of ketones. Serum BOB levels are usually undetectable in patients fed on carbohydrate containing diet.

Previous studies have recommended avoiding propofol when patients are provided KD because of the risk of propofol infusion syndrome[26], [27]. However, use of propofol with KD is probably safe as long as given at low doses $(25-55 \mathrm{mcg} / \mathrm{kg} / \mathrm{min})$ and slowly weaned. The fat component of propofol can affect the ketosis[28], [29] and the calories of patients on propofol need to be adjusted. However, the use of propofol with KD should be tested in larger clinical studies. 
medRxiv preprint doi: https://doi.org/10.1101/2021.07.19.21260800; this version posted July 22, 2021. The copyright holder for this preprint (which was not certified by peer review) is the author/funder, who has granted medRxiv a license to display the preprint in perpetuity. It is made available under a CC-BY-NC-ND 4.0 International license .

1 Since TBI is a catabolic state[30]-[32], we considered using higher protein content which resulted

2 in lower net fat: carbohydrate plus protein ratio $(\mathrm{F}: \mathrm{CP})$. Recent animal studies have found that a ratio

3 of 2:1 formula is better for adults compared to $4: 1[33]$ however that data may not be applicable to

4 adult human TBI patients. In status epilepticus patients, targeting to achieve ketosis with serum

5 BOB levels above $2 \mathrm{mmol} / \mathrm{l}$ helps to better control seizures [17]. No optimal cut-off for serum BOB levels in TBI patients is available, so we followed the trend of serum BOB levels. Whether providing high fat content only without protein is more beneficial needs to be determined in future studies.

$8 \quad$ Hyperglycemia has been associated with worse outcome in neurologically injured patients [34][36]. The recommended blood glucose levels in the ICU setting are 140 - $180 \mathrm{mg} \%$ [36]. Transient hypoglycemia requiring dextrose infusion is uncommon (only 1 of 10 patients). Therefore, the KD may helpavoid hyperglycemia without adverse side effects.

\section{Fat to protein-carbohydrate ratio}

In our study we used Ketovie 4:1 formula which provided higher fat, but not enough proteins. Patients require supplemental protein to fulfill the requirement. These supplements, after correction of the calculation with protein, lower the net $\mathrm{F}: \mathrm{CP}$ ratio. Medium chain triglycerides (MCT) supplementation can be tried to achieve higher ketosis[22] but further studies are needed to understand the effectiveness of higher serum BOB levels.

\section{Potential basis of KD as a therapy}

Based on the existing literature, ketones help in neurological recovery and promotes healing. KD has abundant n-3PUFA which has been shown to mitigate the pathological processes involved in TBI such as mitochondrial dysfunction, apoptotic cell death, glutamate mediated excitotoxicity, and oxidative stress and inflammation [31], [32]. KD also ameliorates the effect of hyperglycemiawhich has been shown to be deleterious after TBI [37], [38]. Even though upregulation of GLUT1, the main 
medRxiv preprint doi: https://doi.org/10.1101/2021.07.19.21260800; this version posted July 22, 2021. The copyright holder for this preprint (which was not certified by peer review) is the author/funder, who has granted medRxiv a license to display the preprint in perpetuity.

It is made available under a CC-BY-NC-ND 4.0 International license .

1 receptor for glucose in the brain, occurs [39], decreases in the glucose levels in the brain as detected

2 by microdialysis studies are present [40], [41]. When KD is used, ketones can enter the Krebs's

3 cycle bypassing glycolysis which helps to generate more adenosine triphosphate (ATP), the main

4 source of energy [33], [42]. KD stabilizes the lactate-pyruvate ratio which is known to be impaired

5 in the TBI [2], [40]. Unidentified mechanisms of KD are also likely present, which are still to be

6 explored.

7 To date, adult human population data about the use of KD in TBI patients is very limited, and the optimal duration of KD therapy has not been defined. This study is the first pilot trial of useof KD

in TBI patients. Some clinical studies have shown that fasting promotes ketone body concentration

10 in cerebral microdialysis (CMD)[43], which suggests a potential therapeuticoption in TBI. Use of

11 intravenous ketone body administration has been shown to improve cerebral metabolism and

12 increase in cerebral blood flow [43], [44]. Our strategy was to provide the benefitof oral KD as an

13 alternative energy source when glucose uptake is diminished in brain.

14

15

16

17

18

\section{Limitations}

The study has significant limitations. A small sample size and a single center study may impact the external validity. All the patients in our trial were Caucasian males. This could be related to higher incidence of TBI in males compared to females[45]. While female patients would not be expected to have a different outcome when on $\mathrm{KD}$, thislimitation needs to be considered in future designing of the studies. Optimal duration of KD therapy is also not defined and we provided the diet only during NSICU stay. Further studies are needed to study the optimal dose and duration of KD in severe TBI patients. We did not measure the cerebral metabolism through microdialysis catheter to understand the role of the KD on the biochemical parameters. However, KD has been shown to have favorable influence on the cerebral metabolism in experimental studies.[46], [47]. 
medRxiv preprint doi: https://doi.org/10.1101/2021.07.19.21260800; this version posted July 22, 2021. The copyright holder for this preprint (which was not certified by peer review) is the author/funder, who has granted medRxiv a license to display the preprint in perpetuity. It is made available under a CC-BY-NC-ND 4.0 International license .

\section{Conclusion}

$\mathrm{KD}$ is feasible and safe in adult patients admitted in ICU with TBI where a complex dynamic environment of multipletherapies take place. While further prospective studies are merited, the study could serve as the preliminary source for understanding the optimal serum BOB levels, dose and duration of KD in TBI and its effect on the outcome.

\section{Acknowledgement}

We thank Ajinomoto Cambrooke pharmaceuticals for providing the KD formulation (Ketovie

4:1) for thestudy purpose. However, no direct funding was provided for the study purpose.

\section{References:}

[1] “Traumatic Brain Injury - Causes, Symptoms and Treatments.” https://www.aans.org/ (accessed Sep. 18, 2020).

[2] M. Prins, T. Greco, D. Alexander, and C. C. Giza, "The pathophysiology of traumatic brain injury at a glance," Dis Model Mech, vol. 6, no. 6, pp. 1307-1315, Nov. 2013, doi: 10.1242/dmm.011585.

[3] K. Fh, "Translational Metabolomics of Head Injury," Brain Neurotrauma, p. 13. [4] "Prognostication in Severe Traumatic Brain Injury in Adults," Palliative Care Network of Wisconsin. https://www.mypcnow.org/fast-fact/prognostication-in-severe-traumatic-brain-injuryin-adults/ (accessed Sep. 22, 2020).

[5] E. H. Kossoff, "More fat and fewer seizures: dietary therapies for epilepsy," The Lancet Neurology, vol. 3, no. 7, pp. 415-420, Jul. 2004, doi: 10.1016/S1474-4422(04)00807-5.

[6] S. Waldbaum and M. Patel, "Mitochondrial dysfunction and oxidative stress: a contributing link to acquired epilepsy?," J Bioenerg Biomembr, vol. 42, no. 6, pp. 449-455, Dec. 2010, doi: 10.1007/s10863-010-9320-9.

[7] S. T. Henderson, "Ketone bodies as a therapeutic for Alzheimer's disease," Neurotherapeutics, vol. 5, no. 3, pp. 470-480, Jul. 2008, doi: 10.1016/j.nurt.2008.05.004.

[8] S. T. Henderson, J. L. Vogel, L. J. Barr, F. Garvin, J. J. Jones, and L. C. Costantini, "Study of the ketogenic agent AC-1202 in mild to moderate Alzheimer's disease: a randomized, doubleblind, placebo-controlled, multicenter trial," Nutr Metab (Lond), vol. 6, p. 31, Aug. 2009, doi: 10.1186/1743-7075-6-31.

[9] R. Nagpal, B. J. Neth, S. Wang, S. Craft, and H. Yadav, "Modified Mediterraneanketogenic diet modulates gut microbiome and short-chain fatty acids in association with Alzheimer's disease markers in subjects with mild cognitive impairment," EBioMedicine, vol. 47, pp. 529-542, Sep. 2019, doi: 10.1016/j.ebiom.2019.08.032.

[10] B. A. Francis, J. Fillenworth, P. Gorelick, K. Karanec, and A. Tanner, "The Feasibility, Safety and Effectiveness of a Ketogenic Diet for Refractory Status Epilepticus in Adults in the Intensive Care Unit," Neurocrit Care, vol. 30, no. 3, pp. 652-657, Jun. 2019, doi: 10.1007/s12028018-0653-2. 
[11] N. Arora and T. R. Mehta, "Role of the ketogenic diet in acute neurological diseases," Clinical Neurology and Neurosurgery, vol. 192, p. 105727, May 2020, doi:

10.1016/j.clineuro.2020.105727.

[12] M. Prins, "DIET, KETONES AND NEUROTRAUMA," Epilepsia, vol. 49, no. Suppl 8, pp. 111-113, Nov. 2008, doi: 10.1111/j.1528-1167.2008.01852.x.

[13] N. R. Stein, D. L. McArthur, M. Etchepare, and P. M. Vespa, "Early Cerebral Metabolic Crisis After TBI Influences Outcome Despite Adequate Hemodynamic Resuscitation," Neurocrit Care, vol. 17, no. 1, pp. 49-57, Aug. 2012, doi: 10.1007/s12028-012-9708-y.

[14] E. Lee, H.-C. Kang, and H. D. Kim, "Ketogenic Diet for Children with Epilepsy: A Practical Meal Plan in a Hospital," Clin Nutr Res, vol. 5, no. 1, pp. 60-63, Jan. 2016, doi: 10.7762/cnr.2016.5.1.60.

[15] I. D’Andrea Meira, T. T. Romão, H. J. Pires do Prado, L. T. Krüger, M. E. P. Pires, and P. O. da Conceição, "Ketogenic Diet and Epilepsy: What We Know So Far," Front Neurosci, vol. 13, Jan. 2019, doi: 10.3389/fnins.2019.00005.

[16] M. C. L. Phillips, D. K. J. Murtagh, L. J. Gilbertson, F. J. S. Asztely, and C. D. P. Lynch, "Low-fat versus ketogenic diet in Parkinson's disease: A pilot randomized controlled trial," Mov Disord, vol. 33, no. 8, pp. 1306-1314, Aug. 2018, doi: 10.1002/mds.27390.

[17] K. T. Thakur et al., "Ketogenic diet for adults in super-refractory status epilepticus," Neurology, vol. 82, no. 8, pp. 665-670, Feb. 2014, doi: 10.1212/WNL.0000000000000151.

[18] “RBR.2440CE.03_rev._04-2017_B-Hydroxybutyrate_LiquiColor.pdf." Accessed: May 28, 2021. [Online]. Available: https://www.ekfusa.com/wpcontent/uploads/2017/08/RBR.2440CE.03_rev._04-2017_B-Hydroxybutyrate_LiquiColor.pdf [19] C. Armstrong, "Endocrine Society Releases Guidelines on Diagnosis and Management of Hypertriglyceridemia," AFP, vol. 88, no. 2, pp. 142-144, Jul. 2013.

[20] N. Carney et al., "Guidelines for the Management of Severe Traumatic Brain Injury, Fourth Edition," Neurosurgery, vol. 80, no. 1, pp. 6-15, Jan. 2017, doi:

10.1227/NEU.0000000000001432.

[21] L. F. Marshall et al., "A new classification of head injury based on computerized tomography," Journal of Neurosurgery, vol. 75, no. Supplement, pp. S14-S20, Nov. 1991, doi: 10.3171/sup.1991.75.1s.0s14.

[22] J. B. Katz et al., "Pearls and Pitfalls of Introducing Ketogenic Diet in Adult Status Epilepticus: A Practical Guide for the Intensivist," J Clin Med, vol. 10, no. 4, Feb. 2021, doi: $10.3390 / \mathrm{jcm} 10040881$.

[23] “6800.00.pdf.” Accessed: May 28, 2021. [Online]. Available: https://www.cancer.org/content/dam/CRC/PDF/Public/6800.00.pdf

[24] R. J. Burstal, J. R. Reilly, and B. Burstal, "Fasting or starving? Measurement of blood ketone levels in 100 fasted elective and emergency adult surgical patients at an Australian tertiary hospital," Anaesth Intensive Care, vol. 46, no. 5, pp. 463-467, Sep. 2018, doi: 10.1177/0310057X1804600506.

[25] "The Feasibility, Safety and Effectiveness of a Ketogenic Diet for Refractory Status Epilepticus in Adults in the Intensive Care Unit | SpringerLink." https://link.springer.com/article/10.1007/s12028-018-0653-2 (accessed Apr. 19, 2021). [26] F. a. M. Baumeister et al., "Fatal propofol infusion syndrome in association with ketogenic diet," Neuropediatrics, vol. 35, no. 4, pp. 250-252, Aug. 2004, doi: 10.1055/s-2004-820992. [27] A. E. Mirrakhimov, P. Voore, O. Halytskyy, M. Khan, and A. M. Ali, "Propofol Infusion Syndrome in Adults: A Clinical Update," Critical Care Research and Practice, vol. 2015, p. e260385, Apr. 2015, doi: 10.1155/2015/260385.

[28] J. Saito et al., "[General anesthesia with propofol for a pediatric patient on a ketogenic 
diet]," Masui, vol. 60, no. 6, pp. 733-735, Jun. 2011.

[29] J. Ichikawa, K. Nishiyama, K. Ozaki, M. Ikeda, Y. Takii, and M. Ozaki, "Anesthetic management of a pediatric patient on a ketogenic diet," J Anesth, vol. 20, no. 2, pp. 135-137, Apr. 2006, doi: 10.1007/s00540-006-0387-8.

[30] B. R. Bistrian, W. Askew, J. W. Erdman, and M. P. Oria, "Nutrition and traumatic brain injury: a perspective from the Institute of Medicine report," JPEN J Parenter Enteral Nutr, vol. 35, no. 5, pp. 556-559, Sep. 2011, doi: 10.1177/0148607111416122.

[31] P. Perel, T. Yanagawa, F. Bunn, I. G. Roberts, and R. Wentz, "Nutritional support for headinjured patients," Cochrane Database Syst Rev, vol. 2006, no. 4, Oct. 2006, doi: 10.1002/14651858.CD001530.pub2.

[32] P. Kurtz and E. E. M. Rocha, "Nutrition Therapy, Glucose Control, and Brain Metabolism in Traumatic Brain Injury: A Multimodal Monitoring Approach," Front Neurosci, vol. 14, Mar. 2020, doi: 10.3389/fnins.2020.00190.

[33] O. Thau-Zuchman et al., "A new ketogenic formulation improves functional outcome and reduces tissue loss following traumatic brain injury in adult mice," Theranostics, vol. 11, no. 1, pp. 346-360, 2021, doi: 10.7150/thno.48995.

[34] J. Shi et al., "Review: Traumatic brain injury and hyperglycemia, a potentially modifiable risk factor," Oncotarget, vol. 7, no. 43, pp. 71052-71061, Sep. 2016, doi: 10.18632/oncotarget.11958.

[35] A. Rovlias and S. Kotsou, "The influence of hyperglycemia on neurological outcome in patients with severe head injury," Neurosurgery, vol. 46, no. 2, pp. 335-342; discussion 342-343, Feb. 2000, doi: 10.1097/00006123-200002000-00015.

[36] G. E. Umpierrez and F. J. Pasquel, "Management of Inpatient Hyperglycemia and Diabetes in Older Adults," Diabetes Care, vol. 40, no. 4, pp. 509-517, Apr. 2017, doi: 10.2337/dc16-0989.

[37] J. Hermanides, M. P. Plummer, M. Finnis, A. M. Deane, J. P. Coles, and D. K. Menon, "Glycaemic control targets after traumatic brain injury: a systematic review and meta-analysis," Crit Care, vol. 22, no. 1, p. 11, Jan. 2018, doi: 10.1186/s13054-017-1883-y.

[38] E. Rostami, "Glucose and the Injured Brain-Monitored in the Neurointensive Care Unit," Front Neurol, vol. 5, Jun. 2014, doi: 10.3389/fneur.2014.00091.

[39] H. Koepsell, "Glucose transporters in brain in health and disease," Pflugers Arch, p. 45, 2020.

[40] I. Jalloh, K. L. H. Carpenter, A. Helmy, T. A. Carpenter, D. K. Menon, and P. J. Hutchinson, "Glucose metabolism following human traumatic brain injury: methods of assessment and pathophysiological findings," Metab Brain Dis, vol. 30, no. 3, pp. 615-632, 2015, doi: 10.1007/s11011-014-9628-y.

[41] J. B. Koenig and C. G. Dulla, "Dysregulated Glucose Metabolism as a Therapeutic Target to Reduce Post-traumatic Epilepsy," Front. Cell. Neurosci., vol. 12, 2018, doi: 10.3389/fncel.2018.00350.

[42] J. C. LaManna et al., "KETONES SUPPRESS BRAIN GLUCOSE CONSUMPTION," Adv Exp Med Biol, vol. 645, pp. 301-306, 2009, doi: 10.1007/978-0-387-85998-9_45.

[43] A. Bernini et al., "Modulation of cerebral ketone metabolism following traumatic brain injury in humans," J Cereb Blood Flow Metab, vol. 40, no. 1, pp. 177-186, Jan. 2020, doi: 10.1177/0271678X18808947.

[44] M. Svart et al., "Regional cerebral effects of ketone body infusion with 3-hydroxybutyrate in humans: Reduced glucose uptake, unchanged oxygen consumption and increased blood flow by positron emission tomography. A randomized, controlled trial," PLoS One, vol. 13, no. 2, Feb. 2018, doi: 10.1371/journal.pone.0190556.

[45] A. Munivenkatappa, A. Agrawal, D. P. Shukla, D. Kumaraswamy, and B. I. Devi, 
1 “Traumatic brain injury: Does gender influence outcomes?," Int J Crit Illn Inj Sci, vol. 6, no. 2, pp. 2 70-73, 2016, doi: 10.4103/2229-5151.183024.

3 [46] M. L. Prins and J. H. Matsumoto, "The collective therapeutic potential of cerebral ketone 4 metabolism in traumatic brain injury," J Lipid Res, vol. 55, no. 12, pp. 2450-2457, Dec. 2014, doi: $5 \quad$ 10.1194/jlr.R046706.

6 [47] M. L. Prins, "Cerebral Metabolic Adaptation and Ketone Metabolism after Brain Injury,” J 7 Cereb Blood Flow Metab, vol. 28, no. 1, pp. 1-16, Jan. 2008, doi: 10.1038/sj.jcbfm.9600543.

\section{Figure Legends}

Figure 1: Flowchart screening patients using inclusion/exclusion criteria

Figure 2: Plots of serum BOB levels $(\mathrm{mmol} / \mathrm{l})$ with time for each patient. Note: BOB values $<0.27$ were truncated to 0.27 . There is fluctuation in the values of the serum BOB levels.

Figure 3: Linear relationship between serum BOB levels (mmol/l) and time (days). 
medRxiv preprint doi: https://doi.org/10.1101/2021.07.19.21260800; this version posted July 22, 2021. The copyright holder for this preprint (which was not certified by peer review) is the author/funder, who has granted medRxiv a license to display the preprint in perpetuity. It is made available under a CC-BY-NC-ND 4.0 International license .

2 Figure 4: Plot of serum glucose $(\mathrm{mg} \%)$ with time for each patient. There is decrease in serum glucose levels 3 with time.

Figure 5: : Linear relationship between Glucose levels (mg\%) and time (days). 
Table 1: Derivation of the fat:Carbohydrate-Protein ratio (F:CP)

\begin{tabular}{|c|c|c|c|c|c|c|c|c|c|c|c|}
\hline Patient & IBW (kg) & $\begin{array}{l}\text { Admission } \\
\text { weight }(\mathrm{Kg})\end{array}$ & $\begin{array}{l}\text { Calorie } \\
\text { Requirement } \\
\text { (Kcal/day) } \\
\end{array}$ & $\begin{array}{l}\frac{\text { Protein }}{\text { Requirement }} \\
\text { (grams/day) }\end{array}$ & $\begin{array}{l}\text { Calories from } \\
\text { ketovie 4:1 } \\
\text { (Kcal) } \\
\end{array}$ & $\begin{array}{l}\text { Protein from } \\
\text { ketovie 4:1 } \\
\text { (grams) } \\
\end{array}$ & $\begin{array}{c}\frac{\text { Net CHO }}{\text { from }} \\
\text { ketovie 4:1 } \\
\end{array}$ & $\begin{array}{l}\text { Protein } \\
\text { supplement } \\
\text { (Grams) } \\
\end{array}$ & $\begin{array}{l}\text { Calories from } \\
\text { supplement } \\
\text { (Kcal) } \\
\end{array}$ & $\begin{array}{l}\text { Fat intake from } \\
\text { Ketovie } \\
\text { 4:1(grams/day) }\end{array}$ & \begin{tabular}{|l|} 
Ratio of \\
Fat:Protein+ \\
net CHO \\
\end{tabular} \\
\hline 1 & 86.4 & 118.8 & 2160 & 132.5 & 1800 & 42.5 & 1.24 & 90 & 360 & 177 & 1.3:1 \\
\hline 2 & 72.7 & 83.6 & 1742 & 122.6 & 1382 & 32.6 & 0.96 & 90 & 360 & 136 & $1.1: 1$ \\
\hline 3 & 82.3 & 92.8 & 2220 & 147.5 & 1800 & 42.5 & 1.24 & 105 & 420 & 177 & $1.19: 1$ \\
\hline 4 & 78 & 87 & 2088 & 133 & 1728 & 40.8 & 1.2 & 90 & 360 & 170 & $1.28: 1$ \\
\hline 5 & 70 & 87.1 & 2088 & 130.8 & 1728 & 40.8 & 1.2 & 90 & 360 & 170 & $1.28: 1$ \\
\hline 6 & 67.3 & 64.6 & 2140 & 105 & 1900 & 44.9 & 1.32 & 60 & 240 & 187 & $1.76: 1$ \\
\hline 7 & 86.3 & 135 & 1855 & 112 & 1555 & 36.7 & 1.08 & 75 & 300 & 153 & $1.36: 1$ \\
\hline 8 & 70 & 127.9 & 1915 & 126.7 & 1555 & 36.7 & 1.08 & 90 & 360 & 153 & $1.35: 1$ \\
\hline 9 & 78.2 & 66.2 & 1569 & 118.6 & 1209 & 28.6 & 0.82 & 90 & 360 & 119 & $1.1: 1$ \\
\hline 10 & 64.5 & 53.6 & 1449 & 88.6 & 1209 & 28.6 & 0.84 & 60 & 240 & 119 & $1.33: 1$ \\
\hline
\end{tabular}

IBW: Ideal Body Weight, CHO: carbohydrate 
medRxiv preprint doi: https://doi.org/10.1101/2021.07.19.21260800; this version posted July 22, 2021. The copyright holder for this preprint (which was not certified by peer review) is the author/funder, who has granted medRxiv a license to display the preprint in perpetuity.

It is made available under a CC-BY-NC-ND 4.0 International license .

Table 2: Feasibility, safety and tolerability outcomes of KD

\begin{tabular}{|c|c|c|c|c|c|c|c|}
\hline Patient & $\begin{array}{l}\text { Time for KD } \\
\text { initiation } \\
\text { from } \\
\text { hospital } \\
\text { admission } \\
\text { (hours) }\end{array}$ & $\begin{array}{l}\text { Baseline } \\
\text { BOB level } \\
\text { (mmol/l) }\end{array}$ & $\begin{array}{c}\text { Ketosis } \\
\text { achieved }\end{array}$ & $\begin{array}{l}\text { Time to } \\
\text { ketosis } \\
\text { (days) }\end{array}$ & $\begin{array}{l}\text { Laboratory } \\
\text { adverse } \\
\text { events }\end{array}$ & $\begin{array}{l}\text { Clinical } \\
\text { adverse } \\
\text { effects }\end{array}$ & $\begin{array}{c}\text { Duration of } \\
\text { KD (days) }\end{array}$ \\
\hline 1 & 24 & $<0.18$ & Yes & 1 & $\begin{array}{l}\text { Hyper-Tg } \\
(540 \mathrm{mg} / \mathrm{dl})\end{array}$ & No & 9 \\
\hline 2 & 16 & $<0.18$ & No & - & none & No & 4 \\
\hline 3 & 30 & 0.55 & Yes & 8 & none & No & 14 \\
\hline 4 & 30 & 0.58 & Yes & 3 & none & No & 12 \\
\hline 5 & 12 & 1.53 & Yes & 1 & none & $\begin{array}{c}\text { Mild } \\
\text { Abdominal } \\
\text { pain }\end{array}$ & 12 \\
\hline 6 & 33 & 0.39 & Yes & 1 & none & No & 6 \\
\hline 7 & 30 & $<0.18$ & Yes & 1 & none & No & 6 \\
\hline 8 & 30 & 0.23 & No & - & $\begin{array}{l}\text { Hyper-Tg } \\
(325 \mathrm{mg} / \mathrm{dl})\end{array}$ & No & 10 \\
\hline 9 & 8 & $<0.18$ & Yes & 1 & none & no & 4 \\
\hline 10 & 18 & 0.29 & yes & 1 & $\begin{array}{l}\text { Hypoglyce } \\
\text { mia }\end{array}$ & no & 8 \\
\hline
\end{tabular}

Hyper-Tg: Hypertriglyceridemia 


\section{Figures with legends:}

Figure 1: Flowchart screening patients using inclusion/exclusion criteria

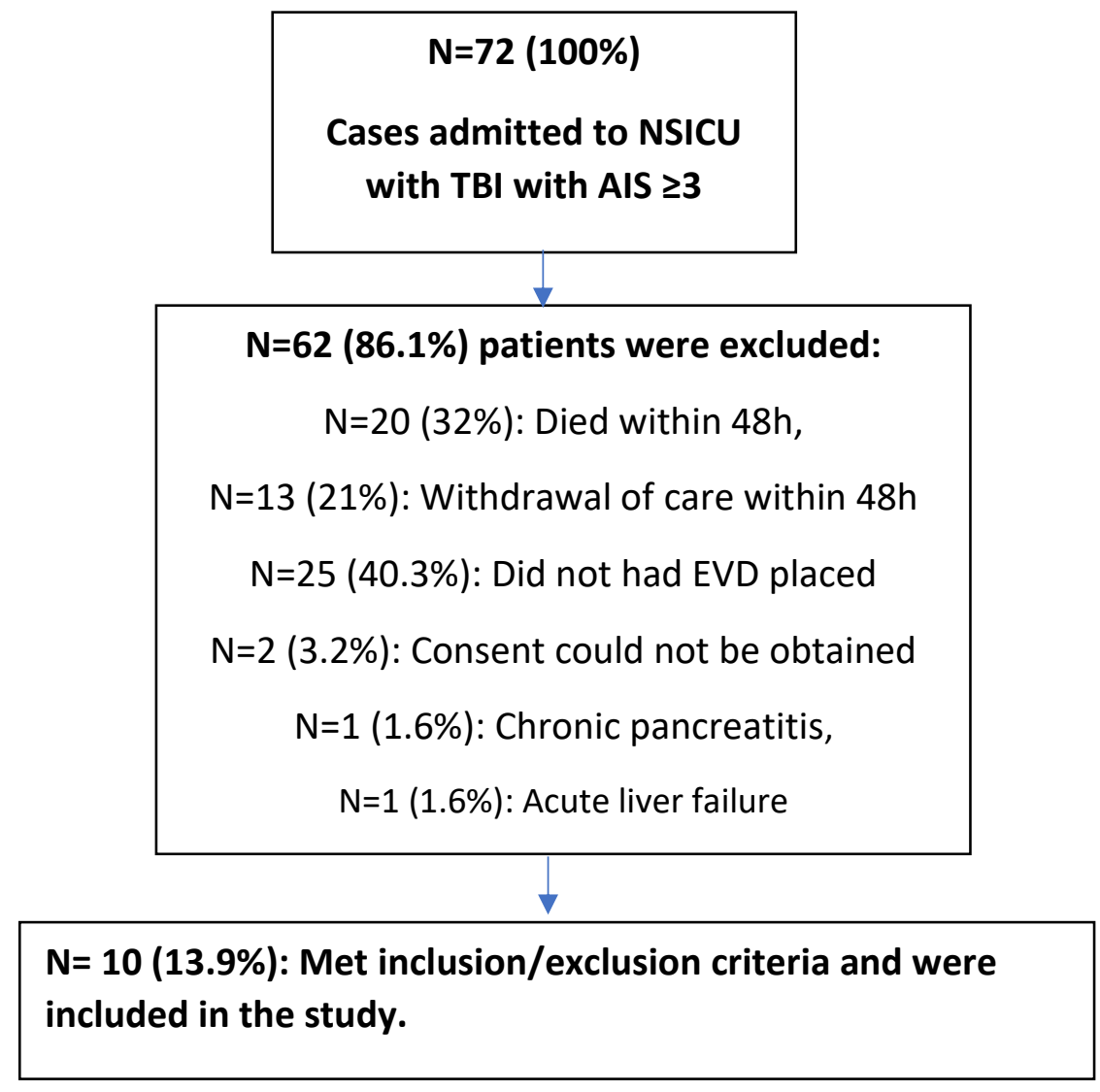


medRxiv preprint doi: https://doi.org/10.1101/2021.07.19.21260800; this version posted July 22, 2021. The copyright holder for this preprint (which was not certified by peer review) is the author/funder, who has granted medRxiv a license to display the preprint in perpetuity.

It is made available under a CC-BY-NC-ND 4.0 International license .

Figure 2: Plots of serum BOB levels $(\mathrm{mmol} / \mathrm{l})$ with time for each patient. Note: $\mathrm{BOB}$ values $<0.27$ were truncated to 0.27 . There is fluctuation in the values of the serum BOB levels.

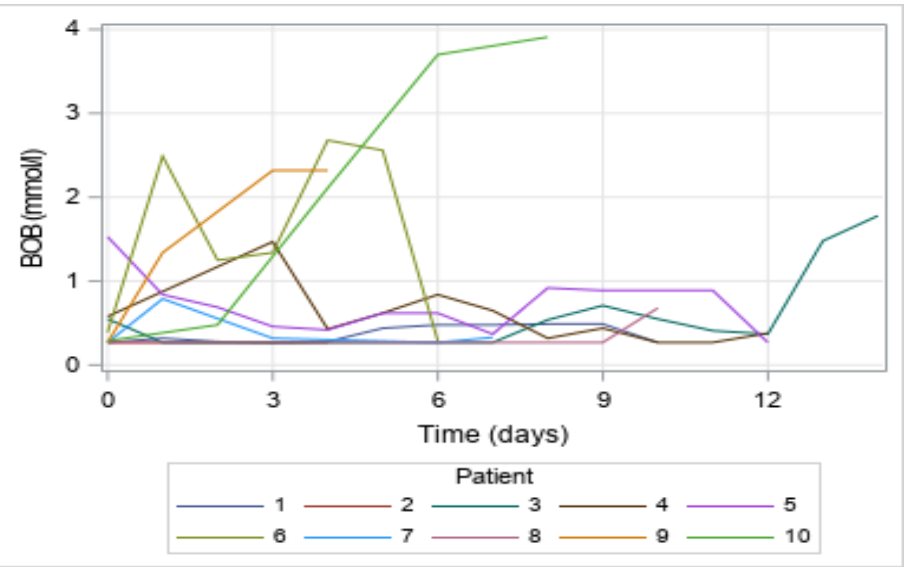

Figure 3: Linear relationship between serum BOB levels (mmol/l) and time (days).

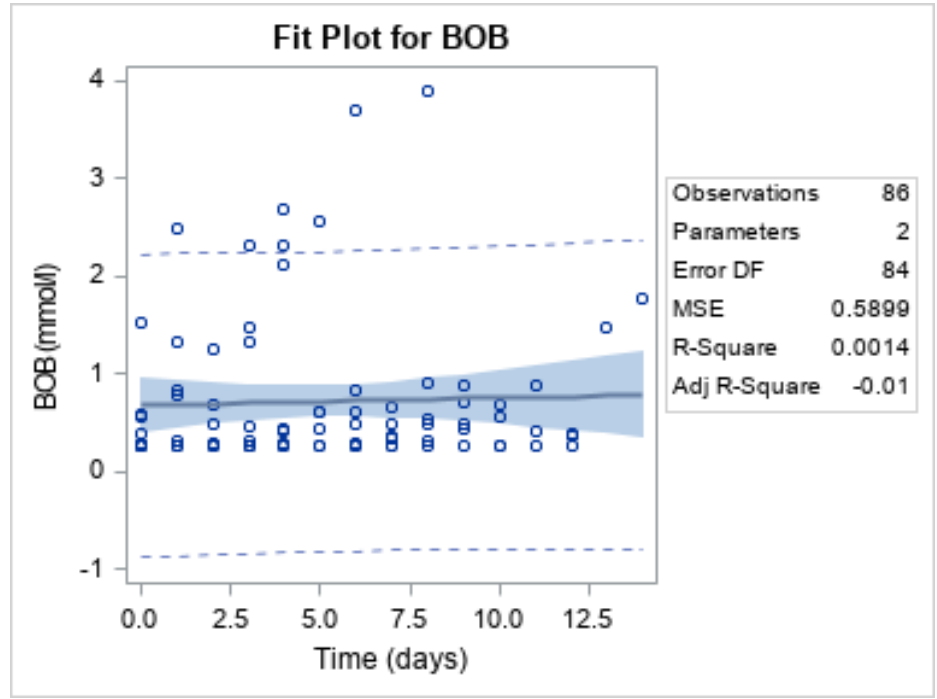

Parameter Estimates

$\begin{array}{llrrrrr}\text { Variable } & \text { Label } & \text { DF } & \begin{array}{r}\text { Parameter } \\ \text { Estimate }\end{array} & \begin{array}{r}\text { Standard } \\ \text { Error }\end{array} & \text { t Value } & \text { Pr }>|\mathbf{t}| \\ \text { Intercept } & \text { Intercept } & \mathbf{1} & 0.67644 & 0.14108 & 4.79 & <.0001 \\ \text { Day } & \begin{array}{l}\text { Time } \\ \text { (days) }\end{array} & \mathbf{1} & 0.00787 & 0.02263 & 0.35 & 0.7289\end{array}$


Figure 4: Plot of serum glucose $(\mathrm{mg} \%)$ with time for each patient. There is decrease in serum glucose levels with time.

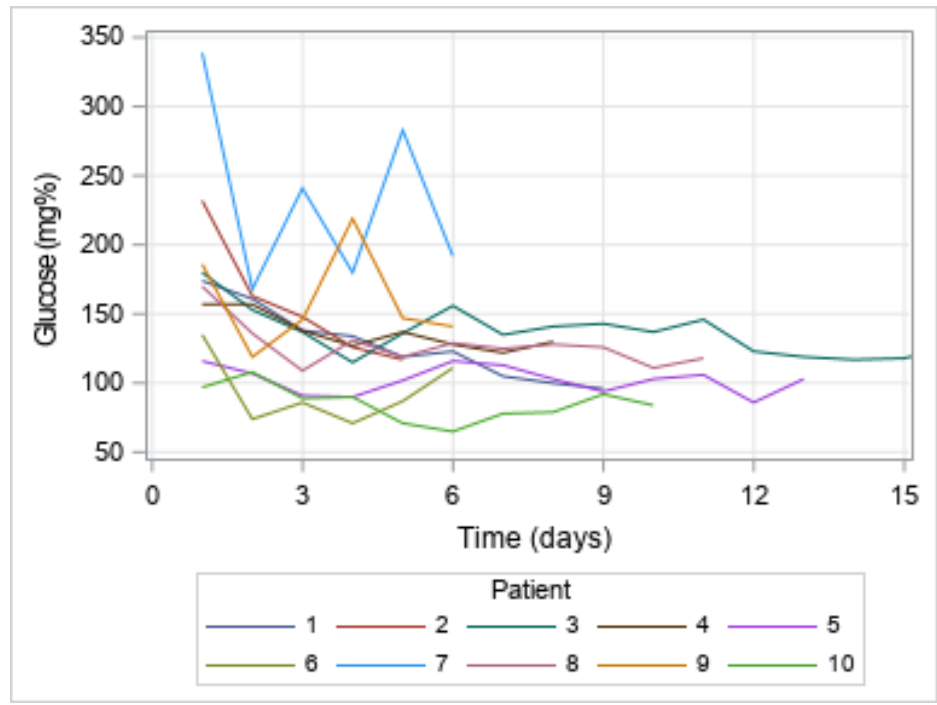

Figure 5: : Linear relationship between Glucose levels (mg\%) and time (days).

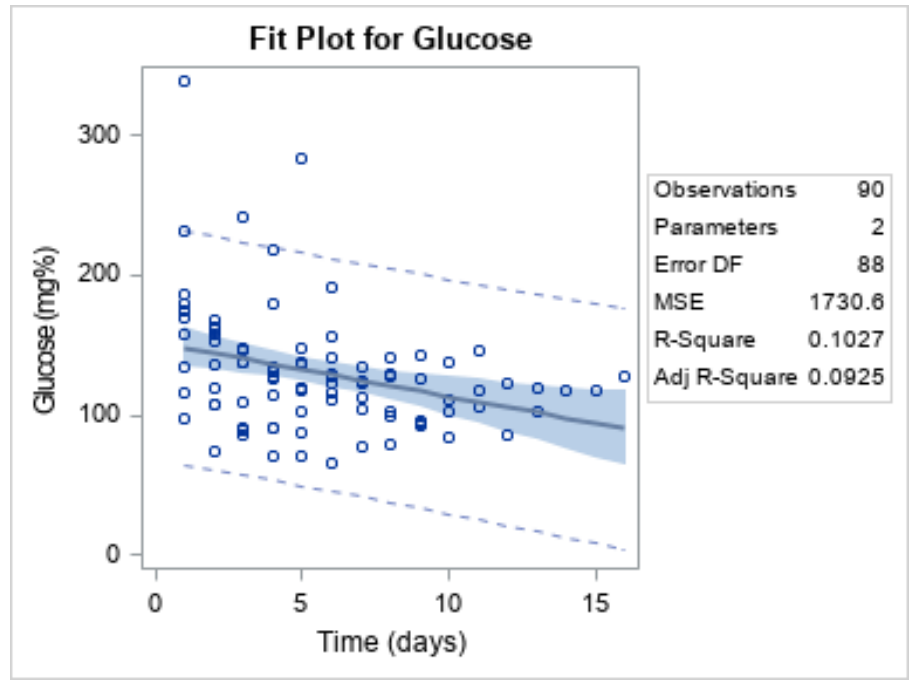

\section{Parameter Estimates}

$\begin{array}{llrrrrr}\text { Variable } & \text { Label } & \text { DF } & \begin{array}{r}\text { Parameter } \\ \text { Estimate }\end{array} & \begin{array}{r}\text { Standard } \\ \text { Error }\end{array} & \text { t Value } & \text { Pr }>|\mathbf{t}| \\ \text { Intercept } & \text { Intercept } & \mathbf{1} & 152.04465 & 8.14206 & 18.67 & <.0001 \\ \text { Day } & \text { Time (days) } & \mathbf{1} & -3.86394 & 1.21781 & -3.17 & 0.0021\end{array}$

